\title{
A comparison of nerve cell loss in cortical and subcortical structures in Alzheimer's disease
}

\author{
DMA MANN, PO YATES, B MARCYNIUK \\ From the Department of Pathology, University of Manchester, Manchester, UK
}

SUMMARY Loss of nerve cells from temporal cortex, hippocampus, nucleus basalis of Meynert and locus caeruleus was measured in 32 patients with Alzheimer's disease ranging from 48 to 92 years of age. Similar changes were present within the cerebral cortex and within the two subcortical structures.

Recent quantitative studies ${ }^{1-21}$ have shown that in Alzheimer's disease there is an atrophy and loss of large neurons from cerebral cortex ${ }^{1-4}$ and hippocampus ${ }^{45}$ and from subcortical areas such as nucleus basalis of Meynert (nbM) ${ }^{6-15}$ and locus caeruleus (LC).$^{15-21}$ Because this conclusion is drawn from the findings of several independent research teams made on separate groups of patients usually of differing ages, and often using different counting techniques, it has not as yet been possible to assess how the extent of cell loss in any one of these affected regions compares with that in the other areas, within the same patients. In this study, we have addressed this question by comparing the extent of cell loss from cortical and subcortical regions of brain in 32 patients with Alzheimer's disease. These data bring together and correlate findings of ours on cell loss in Alzheimer's disease which have been published separately for each area of brain ${ }^{34}$ but have not previously been compared with each other.

\section{Patients and methods}

Brains were obtained at necropsy from 32 moderately to severely demented patients of age range 48-92 years (mean $73.6 \pm 3.0$ years) dying with histologically verified Alzheimer's disease (see Mann et al ${ }^{4}$ for details of pathology). From the formalin fixed brains, tissue blocks were cut from topographically defined areas of temporal cortex ${ }^{4}$ (TCX), hippocampus, ${ }^{4} \mathrm{nbM}^{15}$ and $\mathrm{LC}^{15}$ and from these paraffin sections were cut at $16 \mu \mathrm{m}$ and $20 \mu \mathrm{m}$ (LC) thickness and stained for RNA using Azure B. In these sections either

Address for reprint requests: Dr DMA Mann, Department of Pathology, University of Manchester, Manchester M139PT, UK.

Received 17 May 1985 and in revised form 24 August 1985. Accepted 1 September 1985 the mean number of nucleolated nerve cells per section was counted $^{13151921}$ (nbM and LC) or the mean number of nucleolated nerve cells per $\mathrm{mm}^{3}$ of tissue was estimated 4 (TCX and hippocampus), as we have described else- $\overrightarrow{0}$ where. $^{413151921}$ The mean values of nerve cell number fof $\omega$ these 32 patients together with age-matched control values taken from a series of 67 mentally able patients of age range 10-97 years ${ }^{4}$ are given for each area of brain in oth reports $^{34}$ and are, therefore, not reproduced here. For each patient percentage loss of nerve cells from each area was calculated by comparing actual patient values of cell couriss with those expected for age alone (values derived from control data taken from 67 mentally able patients of age range $\overrightarrow{0}$ 10-97 years ${ }^{4}$ and published by us elsewhere. ${ }^{4} 151921$ ) In this way the variable cell loss present in Alzheimer's disease due simply to growing old could be compensated for, and the extent of cell loss from each area of brain made more easily comparable.

\section{Results}

Although within each area of cortex and subcortex the extent of cell loss (for age) tended to decrease with increasing age (see also Mann et $a l^{4}{ }^{1521}$ ), changes across both cortical and subcortical areas were broadly similar, either when taken overall for all $32 \overline{\bar{z}}$ patients, or when considered at the different age cate- 0 gories (table). Overall, there was some tendency $\left(p<\frac{0}{3}\right.$ 0.05 ) for cell loss in LC and TCX layer V to be greater than that in nbM and hippocampus, and this was 0 largely a reflection of such a trend in the younger 2 rather than the older patients (table). This broadly을 similar pattern of cell loss within cortex and subcortex $>$ was also seen in Spearman correlation statistics in which the extent of cell loss in one region was cor- $N$ related with that in the others, for all 32 patients (LC ${ }^{\circ}$ with nbM, TCX III, TCX V and hippocampus; $r=$ N 310 
$0.520 \mathrm{p}<0.001 ; \mathrm{r}=0.586 \mathrm{p}<0.001 ; \mathrm{r}=0.556 \mathrm{p}<$ $0.001 ; \mathrm{r}=0.548 \mathrm{p}<0.001$ respectively: $\mathrm{nbM}$ with TCX III, TCX V and hippocampus; $r=0.556 \mathrm{p}<$ $0.001 ; r=0.447 p<0.01 ; r=0.306 p<0.05$ respectively: TCX III with TCX V and hippocampus; $r=0.790 \mathrm{p}<0.001 ; \mathrm{r}=0.548 \mathrm{p}<0.001$ respectively: TCX V with hippocampus $r=0.555 \mathrm{p}<$ $0 \cdot 001)$.

\section{Discussion}

The concept ${ }^{22}$ that a failure of subcortical systems using specific neurotransmitters underlies the cortical changes of Alzheimer's disease is attractive because of its obvious therapeutic implications. However, the findings shown here that cortical nerve cells are damaged just as severely as those in the subcortex, together with other observations ${ }^{23}$ linking the degree of dementia with extent of degeneration in such large cortical cells, mean that equally important abnormalities are present in cortex as well as subcortex. The pathological relationship between the two regions may be primary, or secondary or may even co-exist in parallel. In this latter context it is possible that, because both cortical and subcortical neuron types show a similar neurofibrillary degeneration, ${ }^{4513151921}$ a common and fundamental abnormality in all these four cell types may underlie the pathogenesis of Alzheimer's disease. Evidence ${ }^{32-27}$ suggests that this abnormality may involve the ability of such cells to produce proteins appropriate to their correct physiological function.

This work was supported in part by a grant to one of us (BM) from the North Western Regional Health Authority. We thank Mrs P Bellinger for the preparation of the manuscript.

\section{References}

${ }^{1}$ Terry RD, Peck A, De Teresa R, Schechter R, Horoupian DS. Some morphometric aspects of the brain in senile dementia of Alzheimer type. Ann Neurol 1981:10: 184-92.

${ }^{2}$ Mountjoy CQ, Roth M, Evans NJR, Evans HM. Cortical neuronal counts in normal elderly control and demented patients. Neurobiol Ageing 1983:4:1-11.

${ }^{3}$ Mann DMA, Yates PO, Marcyniuk B. Correlation between senile plaque and neurofibrillary tangle counts in cerebral cortex and neuronal counts in cortex and subcortical structures in Alzheimer's disease. Neurosci Lett 1985:56:51-5.

${ }^{4}$ Mann DMA, Yates PO, Marcyniuk B. Some morphometric observations on the cerebral cortex and hippocampus in presenile Alzheimer's disease, senile dementia of Alzheimer type and Down's syndrome in middle age. J Neurol Sci 1985:69:139-59.

${ }^{5}$ Ball MJ. Neuronal loss, neurofibrillary tangles and granulovacuolar degeneration in hippocampal cortex of ageing and demented patients. Acta Neuropathol 1977:42:73-80.

${ }^{6}$ Whitehouse PJ, Price DL, Struble RG, Clarke AW, Coyle JT, De Long MR. Alzheimer's disease and senile dementia: Loss of neurones in the basal forebrain. Science 1981:215:1237-9.

${ }^{7}$ Perry RH, Candy JM, Perry EK, et al. Extensive loss of choline acetyl transferase activity is not reflected by neuronal loss in the nucleus of Meynert in Alzheimer's disease. Neurosci Lett 1982:33:311-5.

${ }^{8}$ Mann DMA, Yates PO. Is the loss of cerebral cortical CAT activity in Alzheimer's disease due to degeneration of ascending cholinergic nerve cells? J Neurol Neurosurg Psychiatry 1982:45:936.

${ }^{9}$ Candy JM, Perry RH, Perry EK, et al. Pathological changes in the nucleus of Meynert in Alzheimer's and Parkinson's disease. J Neurol Sci 1983:59:277-89.

${ }^{10}$ Wilcock GK, Esiri MM, Bowen DM, Smith CCT. The nucleus basalis in Alzheimer's disease: cell counts and cortical biochemistry. Neuropathol Appl Neurobiol 1983:9:175-9.

Table Comparison of nerve cell loss from five areas of brain in Alzheimer's disease

\begin{tabular}{|c|c|c|c|c|c|c|c|}
\hline \multirow{2}{*}{$\begin{array}{l}\text { Age } \\
\text { class }\end{array}$} & \multirow[t]{2}{*}{$n$} & \multirow{2}{*}{$\begin{array}{l}\text { Age } \\
\text { (yrs) }\end{array}$} & \multicolumn{5}{|c|}{ Percentage loss of nerve cells } \\
\hline & & & $\begin{array}{l}\text { Temporal } \\
\text { cortex III }\end{array}$ & $\begin{array}{l}\text { Temporal } \\
\text { cortex } V\end{array}$ & Hippocampus & $\begin{array}{l}\text { Locus } \\
\text { caeruleus }\end{array}$ & $\begin{array}{l}\text { Nucleus } \\
\text { basalis }\end{array}$ \\
\hline$<65$ years & 6 & \multirow{7}{*}{$\begin{array}{r}58.3 \\
\pm 2.6 \\
69 \cdot 6 \\
\pm 1 \cdot 2 \\
80.0 \\
\pm 1.0 \\
88.0 \\
\pm 2.5 \\
73.6 \\
\pm 3.0\end{array}$} & \multirow{7}{*}{$\begin{array}{r}74.6 \\
\pm 3.3 \\
65.0 \\
\pm 3.7 \\
55.4 \\
\pm 2.6 \\
37.2 \\
\pm 6.5 \\
57 \cdot 1 \\
\pm 3.0\end{array}$} & \multirow{7}{*}{$\begin{array}{r}70.4 \\
\pm 6.6 \\
65.5 \\
\pm 3.3 \\
57.2 \\
\pm 3.1 \\
48.1 \\
+7.6 \\
59.5 \\
\pm 2.7\end{array}$} & \multirow{7}{*}{$\begin{array}{c}69 \cdot 1 \\
\pm 8 \cdot 4 \\
39 \cdot 5 * * \dagger \\
\pm 10 \cdot 2 \\
49 \cdot 7 \\
\pm 6 \cdot 7 \\
30.0 \\
\pm 7 \cdot 5 \\
46.8 * \dagger \\
\pm 4.5\end{array}$} & \multirow{7}{*}{$\begin{array}{r}86.2 \\
+8.1 \\
79.7 \\
+5.7 \\
53.8 \\
+9.3 \\
50.0 \\
+12.0 \\
64.2 \\
+5.4\end{array}$} & \multirow{7}{*}{$\begin{array}{c}61.7^{*} \\
\pm 5.9 \\
59.0^{*} \\
\pm 4.6 \\
41.9 \dagger \\
\pm 5.8 \\
37.9 \\
\pm 8.3 \\
48.5^{*} \dagger \\
+3.5\end{array}$} \\
\hline $65-74$ years & 7 & & & & & & \\
\hline $0 J-14$ years & & & & & & & \\
\hline $75-84$ years & 12 & & & & & & \\
\hline $85+$ years & 7 & & & & & & \\
\hline $85+$ years & 7 & & & & & & \\
\hline All patients $\ddagger$ & 32 & & & & & & \\
\hline
\end{tabular}

Values are given as mean $( \pm$ SEM) percentage nerve cell loss.

*, ** denotes significantly LESS than mean value in locus caeruleus $p<0.05,<0.01$ respectively.

$\dagger$ denotes mean value significantly LESS than that in temporal cortex layer $\mathrm{V} p<0.05$.

$\ddagger$ denotes mean for all 32 patients from refs 3 and 4 . 
${ }^{11}$ Tagliavini F, Pilleri G. Basal nucleus of Meynert. A neuropathological study in Alzheimer's disease, simple senile dementia, Pick's disease and Huntington's chorea. J Neurol Sci 1983:62:243-60.

${ }^{12}$ Arendt T, Bigl V, Arendt A, Tennstedt A. Loss of neurones in the nucleus basalis of Meynert in Alzheimer's disease, paralysis agitans and Korsakoff's disease. Acta Neuropathol 1983:61:101-8.

${ }^{13}$ Mann DMA, Yates PO, Marcyniuk B. Changes in nerve cells of the nucleus basalis of Meynert in Alzheimer's disease and their relationship to ageing and to the accumulation of lipofuscin pigment. Mech Ageing Dev 1984:25:189-204.

${ }^{14}$ McGeer PL, McGeer EG, Suzuki J, Dolman CE, Nagai T. Aging, Alzheimer's disease and the cholinergic system of the basal forebrain. Neurology (Cleveland) 1984: 34:741-5.

${ }^{15}$ Mann DMA, Yates PO, Marcyniuk B. Presenile Alzheimer's disease, senile dementia of Alzheimer type and Down's syndrome of middle age, all form an agerelated continuum of pathological changes. Neuropathol Appl Neurobiol 1984:20:187-205.

${ }^{16}$ Tomlinson BE, Irving D, Blessed G. Cell loss in the locus caeruleus in senile dementia of Alzheimer type. J Neurol Sci 1981:49:419-28.

${ }^{17}$ Mann DMA, Yates PO, Hawkes J. The noradrenergic system in Alzheimer and multi-infarct dementias. J Neurol Neurosurg Psychiatry 1982:45:113-9.

${ }^{18}$ Bondareff W, Mountjoy CQ, Roth M. Loss of neurones of adrenergic projection to cerebral cortex (nucleus locus caeruleus) in senile dementia. Neurology $(N Y) \frac{\text { ( }}{2}$ 1982:32:164-9.

${ }^{19}$ Mann DMA, Yates PO, Hawkes J. The pathology of the $Z$ human locus caeruleus. Clin Neuropathol 1983:2:1-7.

${ }^{20}$ Iversen LL, Rossor MN, Reynolds GP, et al. Loss of pigmented dopamine- $\beta$-hydroxylase positive cells from $\subseteq$ locus caeruleus in senile dementia of Alzheimer type. 0 Neurosci Lett 1983:39:95-100.

${ }^{21}$ Mann DMA, Yates PO, Marcyniuk B. Monoaminergic neurotransmitter systems in Alzheimer's presenile dementia and in senile dementia of Alzheimer type. Clin Neuropathol 1984:4:199-205.

${ }^{22}$ Rossor MN. Parkinson's disease and Alzheimer's disease

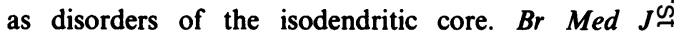
1981:283:1588-90.

${ }^{23}$ Neary D, Snowden JS, Bowen DM, et al. Alzheimer's dis-듬 ease: a correlative study. J Neurol Neurosurg Psychiatry $\overline{\bar{c}}$ (March 1986 issue).

${ }^{24}$ Crapper DR, Quittkat S, De Boni U. Altered chromatin conformation in Alzheimer's disease. Brain 1979:œ 102:483-96.

${ }^{25}$ Crapper McLachlan DR, Lewis PR, Lukiw WJ, Sima A, Bergeron C, De Boni U. Chromatin structure in demen- $\vec{\omega}$ tia. Ann Neurol 1984:15:329-34.

${ }^{26}$ Lewis PN, Lukiw WJ, De Boni U, Crapper McLachlan DR. Changes in chromatin structure associated withọ Alzheimer's disease. $J$ Neurochem 1981:37:1193-202.

${ }^{27}$ Sajdel-Sulkowska E, Marotta CA. Alzheimer's disease brain: alterations in RNA levels and in a ribonuclease- $\omega$ inhibitor complex. Science 1984:225:947-9. 